\title{
Comparison between the Critical Thinking, Educational Self- Efficiency and Motivation of the Female and Male Students of Payam Nour University of Yasouj
}

\author{
Bahram Movahedzadeh $^{1}$ \\ ${ }^{1}$ Assistant professor in department of psychology, Payame Noor University, Iran \\ Correspondence: Bahram Movahedzadeh, Assistant professor in department of psychology, Payame Noor \\ University, Iran. E-mail: movahedbahram@yahoo.com
}

Received: January 21, 2016

Accepted: February 27, 2016

Online Published: June 13, 2016

doi:10.5539/mas.v10n8p84

URL: http://dx.doi.org/10.5539/mas.v10n8p84

\begin{abstract}
The current study aims to compare critical thinking, educational self-efficiency and educational motivation among female and male students of Payam Nour University and to determine effects of critical thinking training on educational achievements and motivation. Differences of these variables among students of various fields also were examined. The sample includes 120 students (60 male students and 60 female students) using stratified random sampling. In order to collect data, three questionnaires of California critical thinking skills test (Form B) (CCTST), Murise's educational self-efficiency small-scale and the questionnaire of Hermans advance motivation were applied. This research is of causal-comparative type and multi-variable variance analysis (Monova) and one-sided analysis were used in order to analyze the data statistically. Data analysis results showed that there was significant difference in critical thinking, educational self-efficiency and educational motivation among female and male students when $\mathrm{p}<0.01$. Moreover, Differences of self-efficacy, critical thinking and motivation among students of different fields were concluded.
\end{abstract}

Keywords: critical thinking, educational self-efficiency, educational motivation

\section{Introduction and Problem Statement}

Since thinking is a process which its fruit is to achieve one of the concepts of argument, assessment, decision making, analysis and inference, it is a mental action and it is proposed when the human encounters the problem and wants to solve it. Currently, one of the main aims of education and training is to emphasize on the development and improvement of the critical thinking skills. The national and international studies know the education and training strategies as the important factors in critical thinking. Therefore, today, very great emphasizes are on training the critical thinking, because the learner is learning many of the rules, ideas and realities in the classrooms (Gyalyam \& Le Grange, 2005).

In addition, Edwards (2007), Halpern (2003) and Pithers and Soden (2000) believe that the high-school students and the university students are subjected to powerful messages which make the effort complicated to execute the critical thinking. A vital demand to critical thinking out of official learning in daily life, relationships, moral choices and keeping and developing the participatory democracies are increasingly rising. These two (critical thinking and motivation) are always influential on the process of discussions and the level of individuals' participations in the activities. On one hand, motivation is among the discussions drawing the investigators' attentions for centuries and the scientists has achieved to this result that evaluating the human's motivation is very complicated. A motivated animal involves in an activity with more power and efficiency than a non-motivated animal (Etkinson, 2000).

Also, another investigated variable playing an influential role in the growth and evolution of individual and human civilization is self-efficiency. Self-efficiency not only affects the quality of organizing the threats, it is also influential on the compatibility of individuals to it. High self-efficiency causes reduction in disturbance against the stressful incidents (Bandura \& Locke, 2003). Bandura (1995) believes that self-efficiency is individual's belief to his/her capability after organizing the required activities. In this way, the individual would be able to present particular performances. Eccles and Wigfield (2002, quoted by Firat, 2010) believe that self-efficiency is the individual's confidence to his/her ability to organize the knowledge and his/her abilities and 
making them practical, so that the problem is solved and the task is accomplished successfully. On this basis, while understanding the students' self-efficiency determines their learning and success through participation in the events of the schools, the student's self-efficiency increases with his/her learning and achievements too. Hence, the studies conducted in this subject represent that high educational self-efficiency has a great influence on the students' educational life (Etem, 2013).

In this regard, Angeli and Valanides (2009) conducted an investigation regarding the influence of the teaching methods in training the critical thinking skills on the students. Four different training methods were applied to teach the critical thinking skills. They achieved this result that the students being in participatory teaching groups had better understanding of the critical thinking. Thomas (1999, quoted by Marin and Halpern, 2011) invited the high-school teachers of Los Angeles area which were trained in the field of critical thinking skills to interview. The subject of interview was about understanding the critical thinking and practicing it. He found that the persons which were trained in the field of critical thinking, had better performance in the field of individuals' participation in class activities and critical thinking skills. The results obtained from this study, supported the wider programs of critical thinking for the teachers all over the California state.

In a research, Joachim Stober and Rambow (2007) investigated on the relations between the motivation of advance, perfectionism, hope to succeed and fear of failure with the symptoms of depression and physical complaints and family pressures. The results represented that negative reactions to the symptoms of depressions and physical complaints were associated with fear of failure.

In an investigation, Yuksel and Alci (2012) proceeded to investigate on the influence of self-efficiency and critical thinking to predict the success of students of Turkey teacher training university and the relation between tendency to critical thinking and educational performance. The results represented that there is a meaningful relation between the scores of self-efficiency and critical thinking. The results obtained from the regression showed that the critical thinking skill of the students of teacher training university is influential on predicting their performance. Uzuntiryaki and Capa (2013) also concluded in a study using structural equations modeling that there is a positive and meaningful relation between chemistry self-efficiency for daily applications and critical thinking. Scheau (2012) investigated the influence of critical thinking on students' development and advance and their informative activities. This research was carried out on the teachers of primary and high schools in Romania. The results represented that applying the critical thinking methods based on the principles of active learning, causes students' advance and public communication. Hence, in this study, it is discussed about investigation on critical thinking, educational self-efficiency and the achievement motivation to be specified.

\subsection{Questions}

1. There is a difference between the female and male students' critical thinkings.

2. There is a difference in achievement motivations between the female and male students.

3. There is a difference between the female and male students' educational self-efficiency.

\section{Methodology}

In the present investigation, causal-comparative method is applied. The statistical society includes all female and male students of Payam Nour university of Yasouj in the educational year of 2014-2015 in which 120 people were selected by categorical random method as the research sample. In this plan, one-way and multivariable variance analysis were applied using statistical tests in order to determine the difference in psychological variables like critical thinking, educational self-efficiency and achievement motivation between both groups.

\subsection{Measurement Tools}

The questionnaire used in this study has contained California critical thinking skills test (Form B). This test contains 34 four-to-five choice questions having a correct answer in five areas of critical thinking cognitive skills (comparison, induction, assessment, analysis, inference).

In this investigation, Murise educational self-efficiency small-scale (2001) is used which has 8 articles. Murise (2001) used the validity coefficients of the educational self-efficiency questionnaire through correlating its articles $(1,2,3,4,5,6,7$ and 8$)$ with the total score of educational self-efficiency as $0.74,0.79,0.68,0.70,0.74$, $0.68,0.74,0.78$ and the stability of the educational self-efficiency through Cronbach alpha which its coefficient is reported as 0.88 .

Achievement motivation questionnaire (AMQ): the achievement motivation questionnaire is a pencil-paper tool provided and written by Hermans (1970) and translated to Persian by Shekarshekan and Boroomand Nasab (2002). This questionnaire has 29 articles which are as inchoate sentences and the choices presented for each 
article is varying from 4 to 6 choices.

\section{Results}

Table 1. Average and standard deviation of students' critical thinking, educational self-efficiency and educational motivation (female and male)

\begin{tabular}{lllll}
\hline Variable & \multicolumn{2}{l}{ Average } & \multicolumn{2}{c}{ Standard deviation } \\
\cline { 2 - 5 } & male & female & male & female \\
\cline { 2 - 5 } Critical thinking & 27.80 & 25.54 & 3.93 & 7.47 \\
Educational self-efficiency & 22.55 & 22.84 & 5.80 & 6.08 \\
Educational motivation & 66.12 & 56.90 & 19.86 & 15.02 \\
\hline
\end{tabular}

As it is observed in table.1, the average (and standard deviation) of the scores of critical thinking of male and female groups are 27.80 (and 3.93) and 25.54 (and 7.47) respectively. Average (and standard deviation) of the scores of educational motivation of male and female groups are 66.12 (and 19.86) and 56.90 (and 15.02) respectively.

Table 2. Average and standard deviation of students' critical thinking, educational self-efficiency and educational motivation (based on the educational course)

\begin{tabular}{lllllll}
\hline Variable & \multicolumn{2}{c}{ Humanities } & \multicolumn{2}{c}{ Technical sciences } & \multicolumn{2}{c}{ Basic sciences } \\
\cline { 2 - 7 } & Average & $\begin{array}{l}\text { Standard } \\
\text { deviation }\end{array}$ & Average & $\begin{array}{l}\text { Standard } \\
\text { deviation }\end{array}$ & Average & $\begin{array}{l}\text { Standard } \\
\text { deviation }\end{array}$ \\
\hline Critical thinking & 23.97 & 3.68 & 34.54 & 49.41 & 26.03 & 9.20 \\
Educational & 22 & 6.05 & 23.22 & 6.41 & 22.56 & 5.85 \\
$\begin{array}{l}\text { self-efficiency } \\
\text { Educational motivation }\end{array}$ & 69.05 & 17.33 & 53.51 & 18.17 & 60.43 & 15.41 \\
\hline
\end{tabular}

As it is observed in table 2, the average (and standard deviation) of the scores of critical thinking of humanities, technical sciences and basic sciences groups are 23.97 (\& 3.68), 34.54 (\& 49.41) and 26.03 (\& 9.20) respectively. The average (\& standard deviation) of the educational self-efficiency of male and female groups are $22(\& 6.05)$ and $23.22(\& 6.41)$ and 26.56 (\& 5.85) respectively. The average (\& standard deviation) of the scores of educational motivation of male and female groups are 69.05 (\& 17.33) and $53.51(\& 18.17)$ and $60.43(\& 15.41)$ respectively.

Table 3. The results of multivariable variance analysis for comparing the average of students' critical thinking, educational self-efficiency and educational motivation (based on the educational course)

\begin{tabular}{llllll}
\hline Test & Value & F & Error $(\mathrm{df})$ & Meaningfulness level & Effect size \\
\hline Pillai's trace & 0.147 & 2.50 & 6 & 0.023 & 0.073 \\
Wilk's Lambda & 0.854 & 2.57 & 6 & 0.020 & 0.76 \\
Hotelling's trace & 0.170 & 2.63 & 6 & 0.018 & 780 \\
Maximum root on & 0.164 & 5.19 & 6 & 0.002 & 0.141 \\
\hline
\end{tabular}

The contents of table. 3 represents that there is a meaningful difference between the educational courses in terms of at least one of the dependent variables (critical thinking, educational self-efficiency and educational motivation). To investigate on this difference accurately, one-way variances analysis was carried out on the dependent variables (humanities, technical sciences and basic sciences groups). The results of this analysis are presented in table4. Table4 represents the results of one-way variance analysis to compare the average of the scores of critical thinkings, educational self-efficiency and educational motivation for the students of educational courses (humanities, technical sciences and basic sciences groups). 
Table 4. The results of one-way variance analysis for comparing the students' average of critical thinking, educational self-efficiency and educational motivation (based on educational field)

\begin{tabular}{llllllll}
\hline Effect & Dependent variable & $\begin{array}{l}\text { Total } \\
\text { squares }\end{array}$ & $\begin{array}{l}\text { Degree } \\
\text { freedom }\end{array}$ & of & $\begin{array}{l}\text { Mean } \\
\text { square }\end{array}$ & F & $\begin{array}{l}\text { Meaningfulness } \\
\text { level }\end{array}$ \\
\hline $\begin{array}{l}\text { Educational } \\
\text { field }\end{array}$ & $\begin{array}{l}\text { Critical thinking } \\
\text { Educational }\end{array}$ & 124.892 & 1 & 124.892 & 4.12 & 0.0001 \\
& $\begin{array}{l}\text { self-efficiency } \\
\begin{array}{l}\text { Educational } \\
\text { motivation }\end{array}\end{array}$ & 4231.744 & 1 & 1 & 98.872 & 3.40 & 0.0001 \\
& & & 4231.744 & 14.27 & 0.0001 \\
\hline
\end{tabular}

The results inserted in table. 4 represent that the one-way variances analysis are meaningful in variables of critical thinking $(\mathrm{F}=4.12 \& \mathrm{p}=0.0001)$, educational self-efficiency $(\mathrm{F}=3.40, \mathrm{p}=0.0001)$ and educational motivation $(\mathrm{F}=14.27 \& \mathrm{p}=0.0001)$. To understand the quality of these differences, it is sufficient to compare the average of educational courses with each other in terms of the mentioned dependent variables. According to the results inserted in table.2, the average of the critical thinking of humanities group, technical sciences group and basic sciences group are 23.97, 34.54 and 26.03 respectively which shows that critical thinking of the technical sciences group is more than the other two groups (humanities and basic sciences). With regard to the score of the educational self-efficiency, humanities group, technical sciences group and basic sciences group are 22, 23.22 and 22.56 respectively which represents that the critical thinking of the technical sciences group is more than the other two groups (humanities and basic sciences). The educational motivation of the humanities group, technical sciences group and basic sciences are 69.05, 53.51 and 60.43 respectively which represents that the critical thinking of the basic sciences group is more than those of the other two groups (basic sciences and technical sciences).

Table 5. Multivariable variance analysis for comparing the students' average of critical thinking, educational self-efficiency and educational motivation (female and male)

\begin{tabular}{llllll}
\hline Test & Value & $\mathrm{F}$ & Error (df) & Meaningfulness level & Effect size \\
\hline Pillai's trace & 0.068 & 2.30 & 3 & 0.082 & 0.068 \\
Wilk's Lambda & 0.932 & 2.30 & 3 & 0.049 & 0.68 \\
Hotelling's trace & 0.072 & 2.30 & 3 & 0.082 & 0.068 \\
Maximum root on & 0.073 & 2.30 & 3 & 0.082 & 0.068 \\
\hline
\end{tabular}

The contents of table.5 represent that there is a meaningful difference between the male and female groups in terms of at least one of the dependent variables (critical thinking, educational self-efficiency and educational motivation). To investigate on this difference accurately, one-way variance analysis was carried out on dependent variables. The results of this analysis are presented in table.6. Table.6 represents the results of one-way variance analysis to compare the average of the scores of critical thinking, educational self-efficiency and educational motivation between female and male groups.

Table 6. One-way variance analysis to compare the average of critical thinking, educational self-efficiency and educational motivation between the students (female and male)

\begin{tabular}{llllllll}
\hline Effect & Dependent variable & $\begin{array}{l}\text { Total } \\
\text { squares }\end{array}$ & $\begin{array}{l}\text { Degree } \\
\text { freedom }\end{array}$ & of & $\begin{array}{l}\text { Mean } \\
\text { squares }\end{array}$ & F & $\begin{array}{l}\text { Meaningfulness } \\
\text { level }\end{array}$ \\
\hline Group & $\begin{array}{l}\text { Critical thinking } \\
\text { Educational }\end{array}$ & 178.145 & 1 & 178.145 & 6.521 & 0.0001 \\
& 80.75 & 1 & 80.75 & 3.35 & 0.810 \\
& $\begin{array}{l}\text { self-efficiency } \\
\text { Educational motivation }\end{array}$ & 2256.250 & 1 & 2256.250 & 7.32 & 0.008 \\
\hline
\end{tabular}

The results inserted in table. 6 represents that the one-way variances analysis is meaningful in the variables of critical thinking $(\mathrm{F}=6.521 \& \mathrm{p}=0.0001)$, educational self-efficiency $(\mathrm{F}=3.35 \& \mathrm{p}=0.810)$ and the educational motivation $(\mathrm{F}=7.32 \& \mathrm{p}=0.0001)$. To understand the quality of these differences, it is enough to compare the average of the scores of male and female groups with each other in terms of dependent variables (critical 
thinking, educational self-efficiency and educational motivation). According to the results inserted in table.1, the average of the score of critical thinking of the male group is 27.80 and it is 25.54 for female group which represents that the critical thinking of the male group is more than the female group. With regard to the score of the educational self-efficiency, the average of the male and female groups is 22.55 and 22.84 respectively which represents that the educational self-efficiencies of the subjects of both groups (female and male) are not very different. With respect to the score of the educational motivation, the average of the male and female groups is 66.12 and 56.90 respectively which represents that the educational self-efficiency of the subjects of the male group is more than the female group.

\section{Discussion and Conclusion}

To explain the findings, it can be stated that considering this fact that the youth period is recognized as an optimal period for developing the cognitive processes of higher ranks, the schools has proceeded less to this problem i.e. forcing the students to ask and discuss. We should focus our concentration on teaching the critical thinking in order to cover the cognitive processes and increase the motivation in high-school period in order to provide the background of self-efficiency more in students with this procedure.

In confirming the effect of teaching the critical thinking and the educational self-efficiency, Etem believes that the individuals whose self-efficiency beliefs is high, have more tendency to participate in the life activities and using more attempt in this activities and development of the effective strategies before the growing challenges. Belief on the influence of the critical thinking training may convert the school to the place of change in cognitive competence, acquiring the knowledge and skills required for solving the problem in order to encounter a greater society influentially. When the students are equipped with the cognitive skills and critical thinking, their feelings of cognitive self-efficiency also increase. Therefore, the school system and the interactive texture between the school members should be in a way that increases the feeling of self-efficiency and educational motivation among the students and it should induct the belief to the students that they have the capability and ability to carry out the tasks.

Additionally, Bandura (2001) believes that there is a meaningful relation between the critical thinking and metacognitive variables like self-efficiency motivation and beliefs. He stated that the individuals' self-assessment of their beliefs in a critical method causes increase in critical thinking. He also points out that the cognitive variables help developing the abilities, beliefs and consequently growth in the skill of critical thinking. Different factors such as participation in class activities in order to compete in the school, assessment of the reference norm, teacher's lower attention to students' qualitative advance may be justifying a reduction in their self-efficiency. In this context, teaching the critical thinking may provide the bed required for individuals in the context of increasing the skills and it may also increase their educational self-efficiency. The critical thinking plays an important role in individuals' educational ability and motivation. It can be stated in this context that the conditions and status of the boys' role in different areas of social, cultural, political and etcetera has resulted in their growth and development in different domains. Of course, in such situations, these conditions are along with a series of impediments and limitations for females which cannot have the boys' freedom of action easily which this factor is an important factor in the context of difference in critical thinking and educational motivation. Otherwise, training a citizen for a democratic society and attendance in a modern pluralist world requires the others' better understanding and better knowledge of the world in a wider area despite the existence of the wide changes in traditional patterns of life and a variety of thoughts, tendencies and information and life in it and its requisite is mutual understanding of peaceful interchanges, tolerance and preparing the opposite votes and views and correct assessment and judgment or in the other words, critical thinking. But what is agreed by most of the professionals is that the skills of the critical thinking are trained in the best way while discussing and interchanging the thought and problem solving (Shaa'bani, 2006).

The critical thinking should make decision based on the available evidences. It should apply the taken decisions in practice and change its procedure if necessary (Malloch \& Porter, 2006). The recent investigations also hold out the agreement between the managers and the teachers about this subject that the students should be prepared in the context of the critical thinking (Kelly et al, 2009). The researches have shown that teaching the critical thinking skills is influential when particular skills are taught during a course. To achieve the reasoning skills, analysis, assessment and decision making, it is necessary to work practically and create an opportunity to transfer the information to the students. Findings of this study can be used by managers and decision makers in universities and schools in scheduling.

\section{References}

Andolina, M. (2001). Critical thinking for working students. Delmar/Thomson Learning. 
Angeli, C., \& Valanides, N. (2009). Instructional effects on critical thinking: Performance on ill-defined issues. Learning and Instruction, 19(4), 322-334.

Atkinson, T. (2000). The Relationship Among of time management principal, Dissertation: university of Connectient. Journal of Personality and Social Psychology, 20, 42-62.

Bandura, A. (2001). Social cognitive theory: An agentic perspective. Annual review of psychology, 52(1), 1-26.

Bandura, A., \& Locke, E. A. (2003). Negative self-efficacy and goal effects revisited. Journal of Applied Psychology, 88(1), 87.

Bonnett, M. (1995). Teaching, thinking and the sanctity of content. Journal of Philosophy of Education, 29(3), 295-309.

Boroomand, N. M. (2002). Investigation on the simple and multiple relation of creativity, achievement motivation and self-esteem with entrepreneurship among the students of Shahid Chamran university of Ahwaz, PHD thesis, faculty of education sciences and psychology.

Edwards, J. (2007). Societal multilingualism: Reality, recognition and response. Handbook of multilingualism and multilingual communication. Berlin: Mouton de Gruyter, 447-467.

Etem, Y. (2013). Academic self-efficacy perceptions of teacher candidates. Mevlane International Journal of Education (MIJE), 3(1), 93-103.

Firat. D. S. (2010). Analysis of academic self-efficiency beliefs of elementary school teacher candidates using different variables. Abant İzet Baysal University Journal of Faculty of Education, 10(1), 69-77.

Gyalyam, N., \& Le-Grange, L. (2005). Improving thinking skills in science of learners with disabilities. South African. Journal of Education, 25, 239- 246

Halpern, D. (2003). Thought and knowledge: An introduction to critical thinking (4th Ed.). Lawrence Eribaum Associates, Inc.

Joachim S., \& Anna, R. (2007) Perfectionism in adolescent school students:

Kelly, K. U., Kit, H., Ho, I. T., \& Halpern, D. (2009). The learning and teaching of critical thinking skills, (senior secondary). Retrieved from http://www.edb.gov.hk

Malloch K. Porter-OGrady (2006). Introduction to Evidence-Based practice in

Marin, L. M., \& Halpern, D. F. (2011). Pedagogy developing critical thinking in adolescents: Explicit instruction produces greatest gains. Thinking Skills and Creativity, 6, 1-13.

Murise, P. (2001). A brief questionnaire for measuring self-efficacy in youths. Journal of Psychopathology and Behavioral Assessment, 23, 145-148. Nursing and Health Care. Ed. Boston: Jones and Bartlett publishers.

Pithers, R. T., \& Soden, R. (2000). Critical thinking in education: A review.

Scheau, I. (2012). The influence of critical thinking on puplis development and at the level of didactic activities. Social and Behavioral Sciences, 51, 752-756.

Shaa'bani, H. (2006). Advanced teaching method (teaching the skills and strategies of thinking), (8th Ed.), Tehran, Semat publications.

Thomas. J. (1999). Facilitation of critical thinking and Deep c0gnitive

Uzuntiryaki, K. E., \& Capa, A. Y. (2013). Predicting critical thinking skill of university students through metacognitive self-regulation skills and chemistry self-efficacy. Educational Sciences: Theory and Practice 13(1), 98-110.

Yuksel, S., \& Alci, B. (2012). Self-efficacy and critical thinking dispositions as predictors of success in school practicum. Journal of Educational Sciences, 4(1), 81-90.

\section{Copyrights}

Copyright for this article is retained by the author(s), with first publication rights granted to the journal.

This is an open-access article distributed under the terms and conditions of the Creative Commons Attribution license (http://creativecommons.org/licenses/by/3.0/). 